\title{
Review on the Work Done For the Last Decade on Acid Soil Management for Better Yields in Southwestern Ethiopia
}

\author{
Tolossa Ameyu \\ Department of Natural Resource Management, Jimma Agricultural Research Center, Jimma, Ethiopia \\ Email address: \\ tolamboo@gmail.com \\ To cite this article: \\ Tolossa Ameyu. Review on the Work Done For the Last Decade on Acid Soil Management for Better Yields in Southwestern Ethiopia. \\ International Journal of Science, Technology and Society. Vol. 9, No. 4, 2021, pp. 162-172. doi: 10.11648/j.ijsts.20210904.13
}

Received: June 25, 2021; Accepted: July 26, 2021; Published: August 5, 2021

\begin{abstract}
Population is increasing exponentially over time but resources are limited. To support this population, increasing productivity of the resources is importantly inevitable. One of the resources, the base of production, is soil. Its fertility is declining due to expansion of soil acidity and its low inherent fertility status. Soil fertility management is therefore, a key for sustainable crop production for food security. Last10-15 years of research and its achievement in soil acidity management in annual crops by Jimma Agricultural research center have been reviewed. To fulfill the increasing demand for food and raw materials, soil health and fertility has remained as the major factor to increase and sustain crop yields. This calls for proper use of knowledge of soil acidity and its amelioration to maximize agricultural productivity. Farmers require simple and sustainable techniques to amend acid soils and improve yields of crops of their choices. Recommendations on reclamation of acid soils need to change with new developments, such as liming, use of acid-tolerant crop varieties and integrated soil fertility management. Liming has played an important role in raising soil $\mathrm{pH}$ and enhancing crop productivity. In Ethiopia, southwestern area the gap between potential and actual yield is very wide because of soil acidity and associated nutrient availability. Acidic soils are not responsive to the application of inorganic fertilizers without amendments-it is simply wastage of resources. Thus, developing effective and efficient acid soil management practices is indispensable for enhancing crop productivity and thereby sustaining yield gains. Natural Resources Management Research process, acid soil management research program of the Jimma Agricultural Research center has been conducting different research activities on soil acidity management to enhance, and sustain agricultural productivity in the country. Using amendments such as lime and organic fertilizer for acid soil management showed good result in maize and soybean productivity in acidic soils in Jimma and Illubabor. This review finding provides important information on management options to amend soil acidity and improve the entire fertility of soils, and other organic amendments that can be applied to remedy soil acidity to the desired $\mathrm{pH}$ level and improve soil quality. Integrated acid soil management enhances the stability of yields and maximizes nutrient use efficiency. The information contained in this finding serves the interests of policymakers, researchers, students, agronomists and users associated with acid soils management.
\end{abstract}

Keywords: Acid Soil, Soil Amendment, Annual Crops, Integrated Soil Fertility Management

\section{Introduction}

Soil fertility is a base for improving production and productivity. Soil fertility management in Jimma Agricultural Research Center is traced back to the late 1970's and to the early 1980's during which yield responses of coffee to N, P and $\mathrm{K}$ application was studied in different coffee growing regions of the country. Since then, it was expanded to mainly grown annual crops in southwestern regions like maize, soybean, common bean and sorghum after soil and water and field crop agronomy research divisions were established at the Center (JARC progress report). These crops play a major role in achieving food security of smallholder farmers in this region.

Soil fertility is declining over time due to low inherent soil fertility and low external inputs. These lead to low and vibrant yields in annual crops. Soil fertility is maintained by applying nutrients from either chemical and/or organic fertilizers. Chemical fertilizers are a type of fertilizer manufactured in industries. They include urea, di-ammonium 
phosphate, triple super phosphate and other forms that are readily available. Organic fertilizers on the other hand are a materials ranging from house wastes to manually prepared materials like compost vermin-compost and green manure. The low organic matter input and continuous ammonium based fertilizer use in Ethiopia exacerbate the acid soil formation. Soil acidification is a complex set of processes resulting in the formation of acid soils. The summation of different anthropogenic and natural processes including leaching of exchangeable bases, basic cation uptake by plants, decomposition of organic materials, application of commercial fertilizers and other farming practices produce acidic soils [3]. Acid soils are highly leached soils with high saturation of $\mathrm{Al}^{+3}$ and $\mathrm{H}^{+}$cations but very low basic cations such as $\mathrm{Ca}^{+2}, \mathrm{Mg}^{+2}$, and $\mathrm{K}^{+}$. It is the most challenging constraint to in crop production in Ethiopia. Soils that affected by acidity is about $43 \%$ of the arable [5] and more serious effect is observed in south western, southern, western and northwestern where rainfall intensity is high and to some extent the central highlands of the country is also affected by mild acidity [11]. Aluminum $\left(\mathrm{A} 13^{+}\right)$toxicity inhibits root cell division and elongation, thereby reducing water and nutrient uptake [15], and cause poor nodulation or mycorrhizal association of roots [4], consequently leading to poor plant growth and yield. Acid soils are poor in fertility and its management should focus towards enriching organic matter in soil. Hand in hand, reclamation of these soils with amendments like lime and organic materials have been believed to be better options for managing such soils. In addition, appropriate type and amount of chemical fertilizer [14], and screening crop varieties for acid soil tolerance are also important practice in making acid soil productive. Jimma agricultural Research Center has been carried out different acid soil and soil fertility management practices since its establishment. Integrated use of lime, leguminous crop and judicious fertilizer are important practices in enhancing soil fertility and improving the productivity of acid soil for annual crops in southwestern and western Ethiopia. Phosphorus nutrition plays important role in legumes and symbiotic N2 fixation. The formation of seeds and fruits is especially depressed in plants suffering from $\mathrm{P}$ deficiency. Thus, not only yields but also poor quality seeds and fruits are obtained from P deficient soils [6]. Liming is a major and effective practice to overcome soil acidity constraints and improve crop production on acid soils. Lime is called the foundation of crop production or "workhorse" in acid soils [7].

\section{Methodology}

This paper reviews various acid soil management practices in annual crops that were conducted by Jimma Agricultural Research Center in the previous decades. It also highlights the major achievements and the future research directions of soil acidity management for sustainable food crop production in the regions.

Table 1. Effect of lime and phosphorus rates on soybean grain yield (ton ha ${ }^{-1}$ ) at Hurumu.

\begin{tabular}{|c|c|c|c|c|c|c|}
\hline Lime $\left(\mathrm{t} \mathrm{ha}^{-1}\right) \& \mathrm{P}\left(\mathrm{kg} \mathrm{ha}^{-1}\right)$ rate & 2009 & 2010 & 2011 & 2012 & 2013 & Mean \\
\hline L0 P0 & 1.44 & 1.16 & $0.38^{\mathrm{h}}$ & $0.57^{\mathrm{g}}$ & $0.62^{\mathrm{i}}$ & $0.84^{\mathrm{g}}$ \\
\hline L0P10 & 1.73 & 1.54 & $1.21^{\mathrm{fg}}$ & $1.63^{\mathrm{a}-\mathrm{d}}$ & $1.39^{\mathrm{e}-\mathrm{g}}$ & $1.50 \mathrm{e}$ \\
\hline L0P20 & 1.37 & 1.34 & $1.78^{\mathrm{a}-\mathrm{e}}$ & $1.84^{\mathrm{a}-\mathrm{c}}$ & $2.25^{\mathrm{ab}}$ & $1.72^{\mathrm{be}}$ \\
\hline L0P30 & 1.60 & 1.55 & $1.93^{\mathrm{a}-\mathrm{d}}$ & $1.73^{\mathrm{a}-\mathrm{d}}$ & $1.74^{\mathrm{ce}}$ & $1.71^{\mathrm{b}-\mathrm{e}}$ \\
\hline $\mathrm{L}_{1.41} \mathrm{P} 0$ & 1.84 & 1.51 & $0.61^{\mathrm{h}}$ & $0.92^{\mathrm{fg}}$ & $0.73^{\text {hi }}$ & $1.12^{\mathrm{f}}$ \\
\hline $\mathrm{L}_{1.41} \mathrm{P} 10$ & 1.83 & 1.88 & $1.54^{\mathrm{d}-\mathrm{f}}$ & $1.49^{\mathrm{c}-\mathrm{e}}$ & $1.81^{\mathrm{b}-\mathrm{e}}$ & $1.71^{\mathrm{b}-\mathrm{e}}$ \\
\hline $\mathrm{L}_{1.41} \mathrm{P} 20$ & 1.57 & 1.34 & $1.38^{\mathrm{ef}}$ & $1.71^{\mathrm{a}-\mathrm{d}}$ & $2.16^{\mathrm{a}-\mathrm{d}}$ & $1.63^{\mathrm{c}-\mathrm{e}}$ \\
\hline $\mathrm{L}_{1.41} \mathrm{P} 30$ & 1.57 & 1.47 & $2.05^{\mathrm{ab}}$ & $1.78^{\mathrm{a}-\mathrm{d}}$ & $2.17^{\mathrm{a}-\mathrm{d}}$ & $1.81^{\mathrm{a}-\mathrm{c}}$ \\
\hline $\mathrm{L}_{2.82} \mathrm{P} 0$ & 1.43 & 1.28 & $0.57^{\mathrm{h}}$ & $0.73^{\mathrm{g}}$ & $1.21^{\mathrm{f}-\mathrm{h}}$ & $1.05^{\mathrm{fg}}$ \\
\hline $\mathrm{L}_{2.82} \mathrm{P} 10$ & 1.89 & 1.64 & $1.69^{b-e}$ & $1.21^{\mathrm{ef}}$ & $1.78^{\mathrm{be}}$ & $1.64^{\mathrm{c}-\mathrm{e}}$ \\
\hline $\mathrm{L}_{2.82} \mathrm{P} 20$ & 1.68 & 1.28 & $1.86^{\mathrm{a}-\mathrm{d}}$ & $1.79^{\mathrm{a}-\mathrm{d}}$ & $2.16^{\mathrm{a}-\mathrm{d}}$ & $1.76^{\mathrm{a}-\mathrm{e}}$ \\
\hline $\mathrm{L}_{2.82} \mathrm{P} 30$ & 1.72 & 2.09 & $1.89^{\mathrm{a}-\mathrm{d}}$ & $1.86^{\mathrm{a}-\mathrm{c}}$ & $2.16^{\mathrm{a}-\mathrm{d}}$ & $1.95^{\mathrm{ab}}$ \\
\hline $\mathrm{L}_{4.23} \mathrm{P} 0$ & 1.74 & 1.53 & $0.79^{\mathrm{gh}}$ & $0.67^{\mathrm{g}}$ & $1.02^{\mathrm{g}-\mathrm{i}}$ & $1.15^{\mathrm{f}}$ \\
\hline $\mathrm{L}_{4.23} \mathrm{P} 10$ & 1.55 & 1.49 & $1.59^{\mathrm{c}-\mathrm{f}}$ & $1.40^{\mathrm{de}}$ & $1.53^{\mathrm{e}}$ & $1.51^{\mathrm{de}}$ \\
\hline $\mathrm{L}_{4.23} \mathrm{P} 20$ & 1.76 & 1.21 & $2.09^{\mathrm{ab}}$ & $1.65^{\mathrm{a}-\mathrm{d}}$ & $2.23^{\mathrm{a}-\mathrm{c}}$ & $1.79^{\mathrm{a}-\mathrm{d}}$ \\
\hline $\mathrm{L}_{4.23} \mathrm{P} 30$ & 1.79 & 1.94 & $2.00^{\mathrm{a}-\mathrm{c}}$ & $2.03^{\mathrm{a}}$ & $2.30^{\mathrm{a}}$ & $2.01^{\mathrm{a}}$ \\
\hline $\mathrm{L}_{5.64} \mathrm{P} 0$ & 1.46 & 1.23 & $1.21^{\mathrm{fg}}$ & $0.68^{\mathrm{g}}$ & $0.91^{\mathrm{g}-\mathrm{i}}$ & $1.10^{\mathrm{fg}}$ \\
\hline $\mathrm{L}_{5.64} \mathrm{P} 10$ & 2.28 & 2.02 & $1.79^{\mathrm{a}-\mathrm{e}}$ & $1.54^{\mathrm{b}-\mathrm{e}}$ & $1.68^{\mathrm{d}-\mathrm{f}}$ & $1.86^{\mathrm{a}-\mathrm{c}}$ \\
\hline $\mathrm{L}_{5.64} \mathrm{P} 20$ & 1.55 & 1.71 & $2.11^{\mathrm{ab}}$ & $1.90^{\mathrm{ab}}$ & $2.11^{\mathrm{a}-\mathrm{d}}$ & $1.88^{\mathrm{a}-\mathrm{c}}$ \\
\hline $\mathrm{L}_{5.64} \mathrm{P} 30$ & 1.72 & 1.39 & $2.13^{\mathrm{a}}$ & $1.97^{\mathrm{a}}$ & $2.13^{\mathrm{a}-\mathrm{d}}$ & $1.87^{\mathrm{a}-\mathrm{c}}$ \\
\hline LSD & NS & NS & 0.44 & 0.41 & 0.49 & 0.29 \\
\hline $\mathrm{CV}$ & 22.65 & 42.57 & 17.22 & 16.86 & 17.43 & 25.1 \\
\hline
\end{tabular}

Means with in a column with the same letter (s) are not significantly different at 0.05 probability level. Ns=Not significantly different.

Source: Soil fertility and plant nutrient management proceeding, Ethiopian Institute of Agricultural Research (EIAR), 2018 ISBN: 978-99944-66-52-8. 


\section{Major Achievements}

\subsection{Lime and P Fertilizer for Maize and Soybean Production}

At Hurumu the findings of experiments show that application of different levels of lime and $\mathrm{P}$ fertilizer revealed that individual year as well as combined over years brought about significant $(\mathrm{P} \leq 0.05)$ interaction effect on grain yield of maize due to different levels of lime and $\mathrm{P}$ fertilizer. As the level of $\mathrm{P}$ increases, grain yield of maize considerable increased. The observed increase in grain yield with increasing $\mathrm{P}$ rate, in non-limed confirmed that $\mathrm{P}$ was a limiting nutrient to maize production. Similar findings were reported [12].

According to Nekessa, [12] maize grain yields increased due to liming of the acid soils and improved nutrition of added $\mathrm{N}$ and $\mathrm{P}$. However, there is no evidence that shows increasing in lime level increased grain yield of maize at Mettu (Hurumu). Generally at Mettu/ Hurumu, applications of 20 and $30 \mathrm{P} \mathrm{kg}$ $\mathrm{ha}^{-1}$ with and without lime gave significantly the high grain yield of maize as compared to the other treatments. However, it could be argued that application of lime for maize at Hurumu could not benefit the crop. Similar result was reported by Brown et al. [8]. The lack of yield response due to liming can probably be attributed to the anticipated high acid buffering capacity of the soil and rendering the lime application levels relatively ineffective [2]. Similarly, Hachalu et al (2012) showed that deficiency of $\mathrm{P}$ could be corrected thought liming acid soil to increase the $\mathrm{pH}$ more than 6 [1].

Similar experiment at the same location on soybean
(2009-2013) revealed that, seed yield was influenced by the interaction of lime and phosphorus fertilizer. The highest and significant seed yield was obtained by application of $1.41,2.82,4.23 \& 5.64 \mathrm{t}$ lime $\mathrm{ha}^{-1}$ along with $30 \mathrm{~kg} \mathrm{P} \mathrm{ha}^{-1}$; 2.82, 4.23 and $5.64 \mathrm{t}^{\text {lime }} \mathrm{ha}^{-1}$ along with $20 \mathrm{~kg} \mathrm{P} \mathrm{ha}^{-1}$ and $5.64 \mathrm{t}^{\text {lime }} \mathrm{ha}^{-1}$ along with $10 \mathrm{~kg} \mathrm{P} \mathrm{ha}{ }^{-1}$. So, this result indicated that liming improves availability of $\mathrm{P}$ for crops and also external $\mathrm{P}$ application improved crop performance. The result further indicate that applying phosphorus fertilizer increases crop growth and yield on soils which are naturally low in $\mathrm{P}$ and in soils that have been depleted [13].

\subsection{Split Application of Lime}

In Jimma/Doyo and Hurumu, responses of maize and soybean to split lime application was also investigated by Acid soil management team of JARC for five consecutive cropping seasons.. Accordingly, the results at Doyo showed that, split application of lime significantly affected maize and soybean yield at Doyo (Table 2). The results showed that application of lime into four equal split gave similar maize grain yield with splitting lime into two and three. This might be due to the less acidity of Doyo area. Result of this experiment revealed that splitting the required amount of lime into two and three for growing maize at this area. At the same location, split and full dose application gave almost similar soybean seed yield (Table 3). Therefore, resource poor farmers who cannot afford the price of full lime requirement at once can split in to two, three or even into four and apply every year without significant yield reduction for growing soybean.

Table 2. Effect of split application of lime on maize grain yield ( $\mathrm{kg} \mathrm{ha-1)}$ at Doyo.

\begin{tabular}{|c|c|c|c|c|c|c|}
\hline Treatment & 2009 & 2010 & 2011 & 2012 & 2013 & Mean \\
\hline Control & $1656 \mathrm{~b}$ & $2524 b$ & 4259 & $2762 \mathrm{c}$ & 1910 & $2622 c$ \\
\hline $25 \%$ every year & $1730 \mathrm{~b}$ & $3370 \mathrm{ab}$ & 4464 & $3671 \mathrm{ab}$ & 1792 & $3005 b c$ \\
\hline $33 \%$ every year & $1756 \mathrm{~b}$ & $3412 \mathrm{ab}$ & 4677 & $4221 \mathrm{a}$ & 2180 & $3249 a b$ \\
\hline $50 \%$ every year & $2176 \mathrm{ab}$ & $3640 \mathrm{ab}$ & 4936 & $3491 \mathrm{ab}$ & 2256 & $3300 \mathrm{ab}$ \\
\hline Full dose & $2798 \mathrm{a}$ & $4163 a$ & 5101 & $3192 b c$ & 2149 & $3481 \mathrm{a}$ \\
\hline $\operatorname{LSD}(0.5)$ & 780 & 1441 & Ns & 784 & Ns & 466 \\
\hline $\mathrm{CV}(\%)$ & 20.48 & 22.36 & 14.83 & 12.01 & 35.88 & 11.09 \\
\hline
\end{tabular}

Means with in a column with the same letter (s) are not significantly different at 0.05 probability level. Ns=Not significantly different.

Table 3. Effect of split application of lime on maize grain yield (kg ha-1) at Hurumu.

\begin{tabular}{|c|c|c|c|c|c|c|}
\hline Treatment & 2009 & 2010 & 2011 & 2012 & 2013 & Mean \\
\hline Control & $5226 \mathrm{c}$ & $4654 b$ & 6804 & $5868 d$ & 5993 & $5709 b$ \\
\hline $25 \%$ every year & $5851 b c$ & $5082 \mathrm{ab}$ & 7115 & $6975 b$ & 5643 & $6133 \mathrm{ab}$ \\
\hline $33 \%$ every year & $6579 \mathrm{ab}$ & $5337 \mathrm{ab}$ & 7127 & $7875 a$ & 5755 & $6535 a$ \\
\hline Full dose & $7439 a$ & $5864 \mathrm{a}$ & 8069 & $6204 c$ & 5616 & $6638 \mathrm{a}$ \\
\hline $\operatorname{LSD}(0.5)$ & 1337 & 1202 & NS & 485 & NS & 725 \\
\hline $\mathrm{CV}(\%)$ & 11.01 & 11.94 & 9.96 & 3.85 & 12.96 & 8.60 \\
\hline
\end{tabular}

Means with in a column with the same letter (s) are not significantly different at 0.05 probability level. Ns=Not significantly different.

Table 4. Effect of split application of lime on soybean seed yield ( $\mathrm{kg} \mathrm{ha-1)}$ at Doyo.

\begin{tabular}{llllll}
\hline Treatment & $\mathbf{2 0 0 9}$ & $\mathbf{2 0 1 0}$ & $\mathbf{2 0 1 1}$ & $\mathbf{2 0 1 2}$ & Mean \\
\hline Control & 1259 & 1185 & $1219 \mathrm{~b}$ & 1705 & 2416 \\
$25 \%$ every year & 1454 & 1541 & $1978 \mathrm{a}$ & 1977 & 2441 \\
$33 \%$ every year & 1674 & 1662 & $2270 \mathrm{a}$ & 1739 & $1878 \mathrm{a}$ \\
\hline
\end{tabular}




\begin{tabular}{|c|c|c|c|c|c|c|}
\hline Treatment & 2009 & 2010 & 2011 & 2012 & 2013 & Mean \\
\hline $50 \%$ every year & 1848 & 1694 & $2275 a$ & 1880 & 2108 & $1961 \mathrm{a}$ \\
\hline Full dose & 1944 & 1780 & $2286 a$ & 1850 & 2408 & $2054 \mathrm{a}$ \\
\hline $\operatorname{LSD}(0.5)$ & Ns & Ns & 638 & Ns & Ns & 294 \\
\hline $\mathrm{CV}(\%)$ & 22.86 & 20.77 & 16.91 & 8.92 & 7.91 & 11.62 \\
\hline
\end{tabular}

Means with in a column with the same letter (s) are not significantly different at 0.05 probability level. Ns=Not significantly different.

Source: Soil fertility and plant nutrient management proceeding, Ethiopian Institute of Agricultural Research (EIAR), 2018 ISBN: 978-99944-66-52-8.

Similar to Doyo site, Hurumu soil was also responsive to split lime application (Tables 4 \& 5). All splits gave statistically comparable maize and soybean yield with full dose of lime application. Therefore, depending on the availability of lime and affordability of maize and soybean growers, it is possible to use either of the above split application frequencies.

Table 5. Effect of split application of lime on soybean seed yield $\left(\mathrm{kg} \mathrm{ha}^{-1}\right)$ at Hurumu.

\begin{tabular}{|c|c|c|c|c|c|c|}
\hline Treatment & 2009 & 2010 & 2011 & 2012 & 2013 & Mean \\
\hline Control & $1382 b$ & 1530 & $1344 b$ & $1436 b$ & 2077 & $1554 b$ \\
\hline $25 \%$ every year & $1421 b$ & 1539 & $1953 a$ & $1766 \mathrm{ab}$ & 2390 & $1814 \mathrm{ab}$ \\
\hline $33 \%$ every year & $1674 \mathrm{ab}$ & 1631 & $2024 a$ & $1858 \mathrm{a}$ & 2170 & $1871 \mathrm{a}$ \\
\hline $50 \%$ every year & $1848 \mathrm{ab}$ & 1709 & $2004 a$ & $1752 \mathrm{ab}$ & 2327 & $1867 \mathrm{ab}$ \\
\hline Full dose & $1944 a$ & 1734 & $2050 \mathrm{a}$ & $1727 \mathrm{ab}$ & 2188 & $1929 a$ \\
\hline $\operatorname{LSD}(0.5)$ & 497 & Ns & 470 & 384 & Ns & 218 \\
\hline CV $(\%)$ & 15.97 & 10.06 & 13.33 & 11.86 & 10.17 & 8.98 \\
\hline
\end{tabular}

Means with in a column with the same letter (s) are not significantly different at 0.05 probability level. Ns=Not significantly different.

Source: Soil fertility and plant nutrient management proceeding, Ethiopian Institute of Agricultural Research (EIAR), 2018 ISBN: 978-99944-66-52-8.

\subsection{Organic Fertilizer as Amendment for Acid Soil Amelioration}

The use of farm yard manure (FYM) alone, compost alone, $1 / 2$ compost + NP, FYM + lime, compost + lime and $1 / 2$ compost $+\mathrm{NP}+$ lime significantly improved soil $\mathrm{pH}$. This approach is important in reducing the acid forming effect of chemical fertilizers. Continuous addition of FYM along with NPK also increases the soil $\mathrm{pH}$ as compared to the use of NPK alone [14].

Table 6. Effect of inorganic and organic fertilizers and lime on chemical properties of Acid soil.

\begin{tabular}{|c|c|c|c|c|c|}
\hline Treatment & $\mathbf{p H}$ & Exc. Acidity (Cmol kg-1) & Available P (mg kg-1) & CEC (Cmol kg-1) & OC (\%) \\
\hline Control & $4.6 \mathrm{c}$ & $3.4 \mathrm{a}$ & $0.9 \mathrm{bc}$ & $35.9 a$ & $1.5 b$ \\
\hline NP & $4.6 \mathrm{c}$ & $2.9 \mathrm{ab}$ & $1.4 \mathrm{a}$ & $27.1 \mathrm{ab}$ & $1.8 \mathrm{ab}$ \\
\hline FYM & $4.8 \mathrm{ab}$ & $2.5 \mathrm{bc}$ & $1.1 \mathrm{abc}$ & $29.0 \mathrm{ab}$ & $1.9 \mathrm{a}$ \\
\hline Compost & $4.9 \mathrm{a}$ & $1.6 \mathrm{ed}$ & $1.2 \mathrm{abc}$ & $34.1 \mathrm{a}$ & $1.8 \mathrm{a}$ \\
\hline $1 / 2(\mathrm{FYM}+\mathrm{NP})$ & $4.6 \mathrm{c}$ & $3.0 \mathrm{ab}$ & $1.2 \mathrm{abc}$ & $33.3 \mathrm{ab}$ & $1.7 \mathrm{ab}$ \\
\hline $1 / 2($ compost $+\mathrm{NP})$ & $4.8 \mathrm{ab}$ & $2.0 \mathrm{cde}$ & $1.4 \mathrm{a}$ & $33.9 \mathrm{a}$ & $1.7 \mathrm{ab}$ \\
\hline FYM + Lime & $4.8 \mathrm{ab}$ & $2.3 b c$ & $0.9 \mathrm{bc}$ & $30.3 \mathrm{ab}$ & $1.8 \mathrm{a}$ \\
\hline $\mathrm{NP}+$ lime & $4.7 \mathrm{bc}$ & $2.3 \mathrm{bcd}$ & $1.1 \mathrm{abc}$ & $23.1 \mathrm{~b}$ & $1.9 \mathrm{a}$ \\
\hline $1 / 2(\mathrm{FYM}+\mathrm{NP})+$ Lime & $4.7 \mathrm{bc}$ & $2.6 b c$ & $1.1 \mathrm{abc}$ & $28.4 \mathrm{ab}$ & $1.9 \mathrm{a}$ \\
\hline $1 / 2($ compost $+\mathrm{NP}+$ lime $)$ & $4.8 \mathrm{ab}$ & $2.0 \mathrm{cde}$ & $1.3 \mathrm{ab}$ & $31.5 \mathrm{ab}$ & $1.9 \mathrm{a}$ \\
\hline LSD0.05 & 0.2 & 0.7 & 0.4 & 10.6 & 0.3 \\
\hline CV (\%) & 2.5 & 17.9 & 20.1 & 20.0 & 8.8 \\
\hline
\end{tabular}

Means with in a column with the same letter (s) are not significantly different at 0.05 probability level.

Organic fertiliser application has been reported to improve crop growth by supplying plant nutrients as well as improving soil physical, chemical, and biological properties [10]. Application of organic fertilizers along with recommended rates of chemical fertilizer increased the maize productivity to the maximum level, which might be due to the improvement in soil health i.e. microbial activity, $\mathrm{pH}$, $\mathrm{CEC}, \mathrm{OM}$ etc and release of organic acids that bind aluminum ( $\mathrm{Al})$ and iron $(\mathrm{Fe})$, thereby reducing $\mathrm{P}$ fixation and increasing its availability [10].

Over year analysis indicated that recommended NP, 50\% $\mathrm{FYM}+50 \% \mathrm{NP}$, recommended NP + lime and 50\% FYM + $50 \% \mathrm{NP}+50 \%$ lime gave significantly $(\mathrm{P} \leq 0.05)$ superior grain yield of maize as compared to the other organic fertilizers. This could be due to the provision of readily available plant nutrients from chemical fertilizers. Application of organic fertilizers along with recommended rates of fertilizers increased the maize productivity to the maximum level, which might be due to the improvement in soil health i.e. microbial activity, $\mathrm{pH}, \mathrm{CEC}$, OM etc and release of organic acids that bind aluminum (Al) and iron (Fe), thereby reducing $\mathrm{P}$ fixation and increasing its availability [10]. This investigation suggests recommending the use of organic fertilizer alongside with lime and mineral fertilizers to increase maize yields. Similar results were reported by Verde et al. (2013) who found that the use of 
manure together with lime and mineral fertilizers to increase soybean yields [14]. The high yields observed under combination of manure, NP fertilizer and lime application might be as a result of its ability for improving soil biological and physical properties which increase soil water retention and enhance nutrient uptake [8].

Nitrogen and Phosphorus Requirements of Maize under Limed Conditions of Acid Soils

Nitrogen and phosphorus requirement of maize was estimated after liming the soil. In this investigation different combinations of nitrogen and phosphorus significantly $(\mathrm{P}<$ 0.05) influenced grain yield of maize in 2011 and 2012 cropping seasons. There was no difference between 69/10, $46 / 20,46 / 30$ and 69/20 N/P Kg ha ${ }^{-1}$ combinations and they resulted in significantly higher yield than the control in 2011 at Jimma (Table 6). However, the yield of the crop grown in 20 and $30 \mathrm{~kg} \mathrm{P} \mathrm{ha}{ }^{-1}$ combined with 46 and $69 \mathrm{~kg} \mathrm{~N}^{-1}$ resulted in better yield than other combinations. The significant increment of maize grain yield by the combined application of NP fertilizers along with lime, and to some extent, only $\mathrm{N}$ and $\mathrm{P}$ together with lime might show liming does not only enhance soil organic $\mathrm{N}$ and $\mathrm{P}$ mineralization in the experimental soils but it facilitates uptakes of the applied inorganic $\mathrm{N}$ and $\mathrm{P}$ fertilizers by the crop. Hachalu et al. (2012) also highlighted the possibility of increasing the crop yield by improving soil acidity through the application of lime, $\mathrm{N}$ and $\mathrm{P}$ fertilizers [1].

Table 7. Grain yield of maize $\left(\mathrm{kg} \mathrm{ha}^{-1}\right)$ as influenced by combinations of lime, organic and inorganic fertilizers at Jimma.

\begin{tabular}{|c|c|c|c|c|c|}
\hline \multirow{2}{*}{ Treatment } & \multicolumn{4}{|c|}{ Grain yield $\left(\mathrm{q} \mathrm{ha}^{-1}\right)$} & \multirow[b]{2}{*}{ Mean } \\
\hline & 2010 & 2011 & 2012 & 2013 & \\
\hline Control & $20.73 d$ & $17.64 \mathrm{c}$ & $14.39 d$ & $26.22 \mathrm{e}$ & $19.75 f$ \\
\hline Recommended NP & $50.83 a$ & $36.51 \mathrm{~b}$ & $31.91 \mathrm{a}$ & $38.20 \mathrm{abc}$ & $39.36 \mathrm{ba}$ \\
\hline $100 \%$ FYM & $25.27 \mathrm{~cd}$ & $25.62 b c$ & $15.64 \mathrm{~cd}$ & $29.89 \mathrm{de}$ & $24.11 \mathrm{ef}$ \\
\hline $100 \%$ compost & $31.98 \mathrm{bcd}$ & $25.64 b c$ & $15.95 \mathrm{~cd}$ & $37.22 \mathrm{bcd}$ & $27.70 \mathrm{ed}$ \\
\hline $1 / 2(\mathrm{FYM}+\mathrm{NP})$ & $37.27 \mathrm{bc}$ & $34.50 \mathrm{~b}$ & $28.41 \mathrm{ab}$ & $43.95 \mathrm{ab}$ & $36.03 \mathrm{bac}$ \\
\hline $1 / 2($ compost $+\mathrm{NP})$ & $33.19 \mathrm{bcd}$ & $41.21 \mathrm{ab}$ & $26.90 \mathrm{abc}$ & $40.08 \mathrm{ab}$ & $35.35 \mathrm{bc}$ \\
\hline Compost + lime & $35.45 b c$ & $26.33 b c$ & $20.09 \mathrm{bcd}$ & $41.73 \mathrm{ab}$ & $30.90 \mathrm{dc}$ \\
\hline $\mathrm{NP}+$ lime & $35.69 b c$ & $52.96 \mathrm{a}$ & $35.62 \mathrm{a}$ & $43.35 \mathrm{ab}$ & $41.91 \mathrm{a}$ \\
\hline $1 / 2(\mathrm{FYM}+\mathrm{NP})+$ Lime & $39.18 \mathrm{ab}$ & $32.02 b c$ & $29.54 \mathrm{ab}$ & $44.56 \mathrm{ab}$ & $36.33 \mathrm{bac}$ \\
\hline $1 / 2($ compost $+\mathrm{NP}+$ lime $)$ & $33.73 \mathrm{bcd}$ & $3613 b$ & $2632 \mathrm{abc}$ & $45.38 \mathrm{a}$ & $35.39 \mathrm{bc}$ \\
\hline LSD0.05 & 13.33 & 16.39 & 11.68 & 8.15 & 6.41 \\
\hline CV $(\%)$ & 23.19 & 29.73 & 28.89 & 12.48 & 13.84 \\
\hline
\end{tabular}

Means with in a column with the same letter (s) are not significantly different at 0.05 probability level.

Table 8. Effect of nitrogen and phosphorus on maize yield $(\mathrm{kg} \mathrm{ha-1)} \mathrm{under} \mathrm{limed} \mathrm{acid} \mathrm{soil} \mathrm{at} \mathrm{Jimma} \mathrm{in} \mathrm{three} \mathrm{consecutive} \mathrm{seasons.}$

\begin{tabular}{|c|c|c|c|c|c|}
\hline \multirow{2}{*}{ N (kg ha-1) } & \multirow{2}{*}{ P (kg ha-1) } & \multicolumn{3}{|l|}{ Season } & \multirow{2}{*}{ Mean } \\
\hline & & 2012 & 2013 & 2014 & \\
\hline 0 & 0 & $2888 \mathrm{c}$ & $2856 \mathrm{e}$ & 2386 & 2710.0 \\
\hline 23 & 10 & $4207 \mathrm{abc}$ & $3227 \mathrm{e}$ & 2615 & 3349.7 \\
\hline 46 & 10 & $4218^{\mathrm{abc}}$ & $3485 \mathrm{e}$ & 3066 & 3589.7 \\
\hline 69 & 10 & $5035 \mathrm{ab}$ & 3718 de & 3239 & 3997.3 \\
\hline 23 & 20 & 3902abc & $4550 \mathrm{bdc}$ & 2551 & 3667.7 \\
\hline 46 & 20 & $5231 \mathrm{ab}$ & $5477 \mathrm{a}$ & 2958 & 4555.3 \\
\hline 69 & 20 & $5331 \mathrm{a}$ & $4416 \mathrm{dc}$ & 3150 & 4299.0 \\
\hline 23 & 30 & $3719 b c$ & $4483 \mathrm{bdc}$ & 3369 & 3857.0 \\
\hline 46 & 30 & $4701 \mathrm{ab}$ & $4760 \mathrm{abc}$ & 2670 & 4043.7 \\
\hline 69 & 30 & $5244 \mathrm{ab}$ & $5337 \mathrm{ab}$ & 3249 & 4610.0 \\
\hline LSD (0.05) & & 1593 & 883 & Ns & \\
\hline CV $(\%)$ & & 20.87 & 12.16 & 20.99 & \\
\hline
\end{tabular}

Means with in a column with the same letter (s) are not significantly different at 0.05 probability level. Ns=non significant.

At Hurumu in Ilubabor, application of the highest dose of nitrogen and phosphorus, (P30 + N 69) $\mathrm{Kg}^{-1}$, to the soil of gave the highest maize grain yield (Table 7). In this line, Tadesse etal (2012) reported an increase in maize grain yield in Wollega by the application of nitrogen and phosphorus fertilizers along with the use of $3 \mathrm{t} \mathrm{ha}^{-1}$ calcium Carbonate [1].

Table 9. Effect of nitrogen and phosphorus on maize yield ( $\mathrm{kg} \mathrm{ha-1)} \mathrm{under} \mathrm{limed} \mathrm{condition} \mathrm{at} \mathrm{Hurumu.}$

\begin{tabular}{|c|c|c|c|c|c|}
\hline \multirow{2}{*}{ N (kg ha-1) } & \multirow{2}{*}{ P (kg ha-1) } & \multicolumn{3}{|l|}{ Season } & \multirow{2}{*}{ Mean } \\
\hline & & 2012 & 2013 & 2014 & \\
\hline 0 & 0 & $2075 c$ & $2850 \mathrm{c}$ & $2630 \mathrm{~b}$ & $2740 d$ \\
\hline 23 & 10 & $5390 \mathrm{ab}$ & $4030 a$ & $3170 b$ & $4200 b c$ \\
\hline 46 & 10 & $5790 \mathrm{ab}$ & $3680 \mathrm{bc}$ & $3380 \mathrm{ab}$ & $4290 b c$ \\
\hline 69 & 10 & $5810 \mathrm{ab}$ & $4690 \mathrm{ab}$ & $3310 \mathrm{ab}$ & $4600 \mathrm{bac}$ \\
\hline
\end{tabular}




\begin{tabular}{llllll}
\hline \multirow{2}{*}{ N (kg ha-1) } & \multirow{2}{*}{ P(kg ha-1) } & Season & 2014 & Mean \\
\cline { 3 - 5 } & & $\mathbf{2 0 1 2}$ & $\mathbf{2 0 1 3}$ & $3060 \mathrm{~b}$ & $4770 \mathrm{a}$ \\
\hline 23 & 20 & $5390 \mathrm{ab}$ & $4860 \mathrm{a}$ & $3150 \mathrm{~b}$ & $4050 \mathrm{c}$ \\
46 & 20 & $5760 \mathrm{~b}$ & $3840 \mathrm{bc}$ & $3320 \mathrm{ab}$ & $4460 \mathrm{bac}$ \\
69 & 20 & $6580 \mathrm{ab}$ & $4280 \mathrm{ab}$ & $3070 \mathrm{~b}$ & $4620 \mathrm{bac}$ \\
23 & 30 & $5780 \mathrm{ab}$ & $4240 \mathrm{ab}$ & $3640 \mathrm{ab}$ & $4530 \mathrm{bc}$ \\
46 & 30 & $6230 \mathrm{ab}$ & $4180 \mathrm{ab}$ & $4360 \mathrm{a}$ & $5060 \mathrm{a}$ \\
69 & 30 & 124 & $4590 \mathrm{ab}$ & 107 & 68 \\
LSD $(0.05)$ & & 12.94 & 103 & 18.92 & 14.79 \\
CV (\%) & & 14.52 & & \\
\hline
\end{tabular}

Means with in a column with the same letter (s) are not significantly different at 0.05 probability level.

\section{Integrated Nutrient Management on Maize Grown on Acid Soils}

A study on Integrated Nutrient Management of soil on maize showed that in South western Ethiopia showed that application of organic, inorganic fertilizers and lime significantly affected soil properties such as $\mathrm{pH}$, exchangeable acidity, available phosphorus, organic carbon content and cation exchange capacity (Table 8). The use of farm yard manure (FYM) alone, compost alone, $1 / 2$ compost + $\mathrm{NP}, \mathrm{FYM}+$ lime, compost + lime and $1 / 2$ compost $+\mathrm{NP}+$ lime significantly improved soil $\mathrm{pH}$ as compared to other treatments. It is well known that the organic manure and lime application in acid soil are increase the degree of base saturation and buffering capacity of the soil. This approach is important to reduce unfavorable effect of acid forming chemical fertilizers. The ameliorating effect of lime on soil acidity has been reported by Obiri-Nyarko [10]. Continuous addition of FYM along with NPK also increases the soil $\mathrm{pH}$ as compared to the use of NPK alone [10].

Table 10. Effect of inorganic and organic fertilizers and lime on chemical properties of Acid soil.

\begin{tabular}{|c|c|c|c|c|c|}
\hline Treatment & $\mathbf{p H}$ & Exc. Acidity (Cmol kg-1) & Available P (mg kg-1) & CEC (Cmol kg-1) & OC (\%) \\
\hline Control & $4.6 \mathrm{c}$ & $3.4 \mathrm{a}$ & $0.9 \mathrm{bc}$ & $35.9 \mathrm{a}$ & $1.5 \mathrm{~b}$ \\
\hline NP & $4.6 \mathrm{c}$ & $2.9 \mathrm{ab}$ & $1.4 \mathrm{a}$ & $27.1 \mathrm{ab}$ & $1.8 \mathrm{ab}$ \\
\hline FYM & $4.8 \mathrm{ab}$ & $2.5 \mathrm{bc}$ & $1.1 \mathrm{abc}$ & $29.0 \mathrm{ab}$ & $1.9 \mathrm{a}$ \\
\hline Compost & $4.9 \mathrm{a}$ & $1.6 \mathrm{ed}$ & $1.2 \mathrm{abc}$ & $34.1 \mathrm{a}$ & $1.8 \mathrm{a}$ \\
\hline $1 / 2(\mathrm{FYM}+\mathrm{NP})$ & $4.6 c$ & $3.0 \mathrm{ab}$ & $1.2 \mathrm{abc}$ & $33.3 \mathrm{ab}$ & $1.7 \mathrm{ab}$ \\
\hline $1 / 2($ compost $+\mathrm{NP})$ & $4.8 \mathrm{ab}$ & $2.0 \mathrm{cde}$ & $1.4 \mathrm{a}$ & $33.9 \mathrm{a}$ & $1.7 \mathrm{ab}$ \\
\hline Compost + lime & $5.0 \mathrm{a}$ & $1.6 \mathrm{e}$ & $1.4 \mathrm{a}$ & $34.7 \mathrm{a}$ & $1.9 \mathrm{a}$ \\
\hline $\mathrm{NP}+$ lime & $4.7 \mathrm{bc}$ & $2.3 \mathrm{bcd}$ & $1.1 \mathrm{abc}$ & $23.1 \mathrm{~b}$ & $1.9 \mathrm{a}$ \\
\hline $1 / 2(\mathrm{FYM}+\mathrm{NP})+$ Lime & $4.7 \mathrm{bc}$ & $2.6 b c$ & $1.1 \mathrm{abc}$ & $28.4 \mathrm{ab}$ & $1.9 \mathrm{a}$ \\
\hline $1 / 2($ compost $+\mathrm{NP}+$ lime $)$ & $4.8 \mathrm{ab}$ & $2.0 \mathrm{cde}$ & $1.3 \mathrm{ab}$ & $31.5 \mathrm{ab}$ & $1.9 \mathrm{a}$ \\
\hline LSD0.05 & 0.2 & 0.7 & 0.4 & 10.6 & 0.3 \\
\hline $\mathrm{CV}(\%)$ & 2.5 & 17.9 & 20.1 & 20.0 & 8.8 \\
\hline
\end{tabular}

Means with in a column with the same letter (s) are not significantly different at 0.05 probability level.

Over year analysis indicated that recommended NP, 50\% $\mathrm{FYM}+50 \% \mathrm{NP}$, recommended $\mathrm{NP}+$ lime and 50\% FYM + $50 \% \mathrm{NP}+50 \%$ lime gave significantly $(\mathrm{P} \leq 0.05)$ superior grain yield of maize as compared to the other organic fertilizers. This could be due to the provision of readily available plant nutrients from chemical fertilizers. Application of organic fertilizers along with recommended rates of fertilizers increased the maize productivity to the maximum level, which might be due to the improvement in soil health i.e. microbial activity, $\mathrm{pH}, \mathrm{CEC}, \mathrm{OM}$ etc and release of organic acids that bind aluminum ( $\mathrm{Al}$ ) and iron
(Fe), thereby reducing $\mathrm{P}$ fixation and increasing its availability [14]. this investigation suggests recommending the use of organic fertilizer alongside with lime and mineral fertilizers to increase maize yields. Similar results were reported by Verde et al. (2013) who found that the use of manure together with lime and mineral fertilizers to increase soybean yields [14]. The high yields observed under combination of manure, NP fertilizer and lime application might be as a result of its ability for improving soil biological and physical properties which increase soil water retention and enhance nutrient uptake [10].

Table 11. Grain yield of maize $\left(\mathrm{kg} \mathrm{ha}^{-1}\right)$ as influenced by combinations of lime, organic and inorganic fertilizers at Jimma.

\begin{tabular}{|c|c|c|c|c|c|}
\hline \multirow{2}{*}{ Treatment } & \multicolumn{4}{|c|}{ Grain yield (q ha $\left.{ }^{-1}\right)$} & \multirow{2}{*}{ Mean } \\
\hline & 2010 & 2011 & 2012 & 2013 & \\
\hline Control & $20.73 d$ & $17.64 \mathrm{c}$ & $14.39 \mathrm{~d}$ & $26.22 \mathrm{e}$ & $19.75 f$ \\
\hline Recommended NP & $50.83 a$ & $36.51 \mathrm{~b}$ & $31.91 \mathrm{a}$ & $38.20 \mathrm{abc}$ & $39.36 \mathrm{ba}$ \\
\hline $100 \%$ FYM & $25.27 \mathrm{~cd}$ & $25.62 b c$ & $15.64 \mathrm{~cd}$ & $29.89 \mathrm{de}$ & $24.11 \mathrm{ef}$ \\
\hline $100 \%$ compost & $31.98 \mathrm{bcd}$ & $25.64 b c$ & $15.95 \mathrm{~cd}$ & $37.22 \mathrm{bcd}$ & $27.70 \mathrm{ed}$ \\
\hline
\end{tabular}




\begin{tabular}{|c|c|c|c|c|c|}
\hline \multirow{2}{*}{ Treatment } & \multicolumn{4}{|c|}{ Grain yield $\left(\mathrm{q} \mathrm{ha}^{-1}\right)$} & \multirow{2}{*}{ Mean } \\
\hline & 2010 & 2011 & 2012 & 2013 & \\
\hline $1 / 2(\mathrm{FYM}+\mathrm{NP})$ & $37.27 \mathrm{bc}$ & $34.50 \mathrm{~b}$ & $28.41 \mathrm{ab}$ & $43.95 \mathrm{ab}$ & $36.03 \mathrm{bac}$ \\
\hline $1 / 2($ compost $+\mathrm{NP})$ & $33.19 \mathrm{bcd}$ & $41.21 \mathrm{ab}$ & $26.90 \mathrm{abc}$ & 40.08ab & $35.35 \mathrm{bc}$ \\
\hline FYM + Lime & $27.90 \mathrm{bcd}$ & $27.45 b c$ & $16.26 \mathrm{~cd}$ & $31.63 \mathrm{cde}$ & $25.81 \mathrm{edf}$ \\
\hline Compost + lime & $35.45 b c$ & $26.33 b c$ & $20.09 \mathrm{bcd}$ & $41.73 \mathrm{ab}$ & $30.90 \mathrm{dc}$ \\
\hline $\mathrm{NP}+$ lime & $35.69 \mathrm{bc}$ & $52.96 \mathrm{a}$ & $35.62 \mathrm{a}$ & $43.35 \mathrm{ab}$ & $41.91 \mathrm{a}$ \\
\hline $1 / 2(\mathrm{FYM}+\mathrm{NP})+$ Lime & $39.18 \mathrm{ab}$ & $32.02 b c$ & $29.54 \mathrm{ab}$ & $44.56 \mathrm{ab}$ & $36.33 \mathrm{bac}$ \\
\hline LSD0.05 & 13.33 & 16.39 & 11.68 & 8.15 & 6.41 \\
\hline CV (\%) & 23.19 & 29.73 & 28.89 & 12.48 & 13.84 \\
\hline
\end{tabular}

Means with in a column with the same letter (s) are not significantly different at 0.05 probability level.

In acid soils, where $P$ fixation is a problem application of FYM releases a range of organic acids that can form stable complexes with $\mathrm{Al}$ and Fe thereby blocking the $\mathrm{P}$ retention sites, and as a result, the availability and use efficiency of $\mathrm{P}$ is improved [2].

\subsection{Screening Acid Tolerant Genotypes}

\subsubsection{Screening Common Bean for Acid Soil Tolerance}

This study was conducted to identify common bean varieties that tolerate acid soil or soil of low $\mathrm{pH}$. The results revealed that variety by amendment by location by season interaction was significant $(p<0.01)$ for both grain yield and plant height. Varietal difference among common bean varieties under both lime amended and un amended acid soil conditions was observed from this study. The highest grain yield (1.989 t/ha) was obtained from SER 119 variety under lime and phosphorus treated treatment, while, the highest grain yield (1.043 t/ha) under un-limed soil conditions. The highest yield under un-limed condition, yield levels are still below the national average (1.59 $\mathrm{t} / \mathrm{ha})$, but the yield of SER 119 variety under limed condition is higher than the national average. In this context, SER 119 variety was recommended for those farmers who have the capacity to apply lime with phosphorus based on the yield performance at both locations (Jimma and Mettu).

Results from several studies revealed genotypic variability in plant growth, physiology, and quality in response to aluminum application [9].

Table 12. Over year and amendment combined mean value of grain yield (Kg/ha) of fifteen common bean varieties at individual location.

\begin{tabular}{|c|c|c|c|}
\hline Varieties & Mettu & Jimma & Combined \\
\hline SER 119 & $1483.3^{a}$ & $1392.6^{\mathrm{ab}}$ & $1438.0^{\mathrm{a}}$ \\
\hline SER 125 & $1276.9^{\mathrm{abc}}$ & $1358.4^{\mathrm{abc}}$ & $1317.7^{\mathrm{ab}}$ \\
\hline Naser & $1421.3^{\mathrm{ab}}$ & $1158.7^{\mathrm{cd}}$ & $1290.0^{\mathrm{ab}}$ \\
\hline Ayenew & $1194.0^{\mathrm{abcd}}$ & $1360.4^{\mathrm{abc}}$ & $1277.2^{\mathrm{ab}}$ \\
\hline Dimtu & $1021^{\text {cdef }}$ & $1350.9^{\mathrm{abc}}$ & $1185.9^{\mathrm{bc}}$ \\
\hline Gofat & $1233.3^{\mathrm{abcd}}$ & $1089.6^{\mathrm{de}}$ & $1161.5^{\mathrm{bc}}$ \\
\hline Melka & $1231.4^{\mathrm{abcd}}$ & $1062.6^{\mathrm{de}}$ & $1147.0^{\mathrm{bc}}$ \\
\hline Bashbash & $838.3^{\mathrm{efg}}$ & $1415.8^{\mathrm{a}}$ & $1127.1^{\mathrm{bc}}$ \\
\hline GLP 2 & $1155.1^{\text {abcde }}$ & $1078.9^{\mathrm{de}}$ & $1117.0^{\mathrm{bcd}}$ \\
\hline Awash -1 & $1324.2^{\mathrm{abc}}$ & $743.2^{\mathrm{f}}$ & $1033.7^{\text {cde }}$ \\
\hline Dame & $905.6^{\mathrm{defg}}$ & $938.6^{\mathrm{ef}}$ & $922.1^{\mathrm{efg}}$ \\
\hline Iboda & $928.1^{\text {defg }}$ & $785.1^{\mathrm{f}}$ & $856.6^{\mathrm{efg}}$ \\
\hline Goberasha & $810^{\mathrm{fg}}$ & $781.7^{\mathrm{f}}$ & $795.9^{\mathrm{fg}}$ \\
\hline Awash Melka & $643.3^{\mathrm{g}}$ & $783.4^{f}$ & $713.4^{\mathrm{g}}$ \\
\hline LSD & 331.07 & 219.38 & 207.47 \\
\hline $\mathrm{CV}$ & 17.93 & 11.94 & 11.26 \\
\hline
\end{tabular}

Where, $\mathrm{CV}=$ coefficient of variation, $\mathrm{LSD}=$ list significant different, Note: Means with the same letters are statistically not significant $(\mathrm{p}>0.05)$ different from each other.

Table 13. Over year combined mean value of grain yield (Kg/ha) of fifteen common bean varieties at individual location under different amendments.

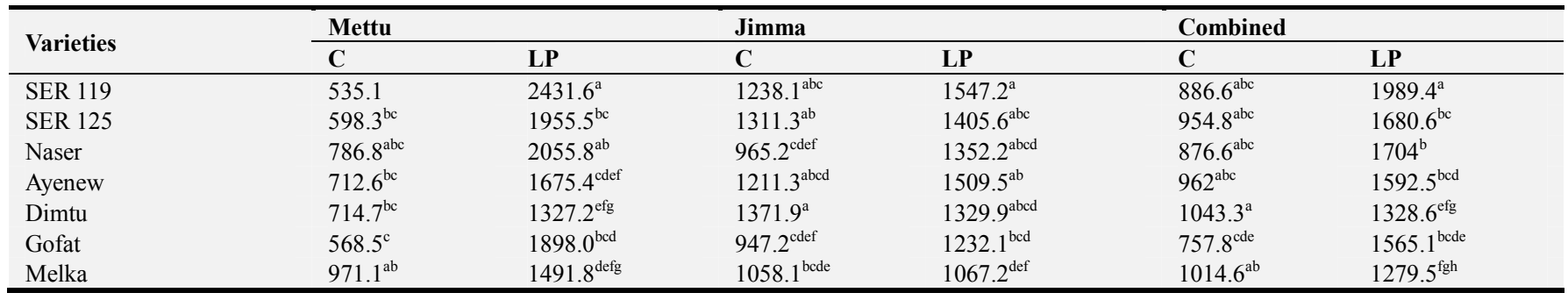




\begin{tabular}{|c|c|c|c|c|c|c|}
\hline \multirow{2}{*}{ Varieties } & \multicolumn{2}{|l|}{ Mettu } & \multicolumn{2}{|l|}{ Jimma } & \multicolumn{2}{|c|}{ Combined } \\
\hline & $\mathrm{C}$ & LP & $\mathrm{C}$ & LP & $\mathbf{C}$ & LP \\
\hline Roba & $485^{\mathrm{c}}$ & $1702.3^{\text {bcde }}$ & $1191.4^{\mathrm{abcd}}$ & $1174.3^{\text {cde }}$ & $838.2^{\mathrm{abc}}$ & $1438.3^{\text {cdef }}$ \\
\hline Bashbash & $443.1^{\mathrm{c}}$ & $1233.5^{\text {fgh }}$ & $1461.8^{\mathrm{a}}$ & $1369.8^{\mathrm{abc}}$ & $952.4^{\mathrm{abc}}$ & $1301.7^{\mathrm{fg}}$ \\
\hline GLP 2 & $689.8^{\mathrm{bc}}$ & $1620.3^{\text {cdef }}$ & $918.9^{\text {def }}$ & $1238.9^{\text {bcd }}$ & $804.3^{\text {bcd }}$ & $1429.6^{\text {def }}$ \\
\hline Awash -1 & $1147.7^{\mathrm{a}}$ & $1500.8^{\text {defg }}$ & $704.5^{\mathrm{f}}$ & $781.8^{\mathrm{f}}$ & $926.1^{\mathrm{abc}}$ & $1141.3^{\mathrm{ghi}}$ \\
\hline Dame & $690.1^{\mathrm{bc}}$ & $1121^{\mathrm{gh}}$ & $992^{\text {cdef }}$ & $885.3^{\text {ef }}$ & $841.1^{\mathrm{abc}}$ & $1003.1^{\mathrm{ij}}$ \\
\hline Iboda & $440.6^{c}$ & $1415.6^{\mathrm{efg}}$ & $712.5^{\mathrm{f}}$ & $857.6^{\mathrm{f}}$ & $576.6^{\mathrm{de}}$ & $1136.6^{\mathrm{ghi}}$ \\
\hline Goberasha & $391.8^{\mathrm{c}}$ & $1228.3^{\mathrm{fgh}}$ & $690.6^{\mathrm{f}}$ & $872.9^{f}$ & $541.2^{\mathrm{e}}$ & $1050.6^{\mathrm{hij}}$ \\
\hline Awash Melka & $397.6^{\mathrm{c}}$ & $889^{\mathrm{h}}$ & $779.3^{\text {ef }}$ & $787.6^{\mathrm{f}}$ & $588.4^{\mathrm{de}}$ & $838.3^{\mathrm{j}}$ \\
\hline Mean & 638.25 & 1569.74 & 1036.94 & 1160.799 & 837.566 & 1365.38 \\
\hline Level of significant & $*$ & $* *$ & $*$ & $* *$ & $* *$ & $* *$ \\
\hline LSD & 397.55 & 427.07 & 304.85 & 291.75 & 233.9 & 249.41 \\
\hline $\mathrm{CV}$ & 37.246 & 16.266 & 17.577 & 15.027 & 16.77 & 10.9223 \\
\hline
\end{tabular}

Where, $\mathrm{C}=$ control, $\mathrm{LP}=$ Lime with phosphorus treated, $\mathrm{CV}=$ coefficient of variation, $\mathrm{LSD}=$ list significant different, Note: Means with the same letters are statistically not significant $(\mathrm{p}>0.05)$ different from each other.

\subsubsection{Screening of Soybean for Acid Soil Tolerance}

Similar to common bean, screening of soybean for its acid soil tolerance was conducted to assess the response of soybean genotypes to lime and phosphorus for yield and to identify soybean genotypes that tolerate low $\mathrm{pH}$ soil. The result revealed that genotype by amendment interaction was significant $(p<0.01)$ for plant height and yields. The maximum grain yields $(2620,2083$ and 1415 and $2047.2 \mathrm{~kg}$ $\mathrm{ha}^{-1}$ ) were obtained under un-limed soil conditions at Jimma, Haru and Mettu respectively from HAWASSA-04, and 2000 $\mathrm{Kg} / \mathrm{ha}$ from combined analysis under control soil condition from HAWASSA-04 variety. The tolerance index value indicated that variety HAWASSA-04 performed well for grain yield and selected as tolerant. The result also verified that application of lime and phosphorus improved grain yield of soybean genotypes. In conclusion, observation of large variation indicates that selection would be effective to improve soybean genotypes performance on acid soils and identify low phosphorus tolerant genotype that helps smallholder farmers optimize soybean productivity on acid soils in the study area. HAWASSA-04 variety is the most tolerant among the tested materials. Therefore for resourcepoor farmers who have no capacity to afford high rates of lime and phosphorus fertilizers, HAWASSA-04 variety is recommended to be used alternatively with clarck-63. However, further screening of large mass of genotypes is important as few genotypes were included the present study.

Studying responses of selected genotypes with contrasting tolerance to aluminum toxicity may help in generating information that could be utilized by breeding programs aimed at developing aluminum-tolerant cultivars for areas where aluminum-induced soil acidity remains a key environmental constraint to crop production [8].

Table 14. Tolerance and susceptibility index of common bean varieties for yield at individual locations and combined on acid soil.

\begin{tabular}{|c|c|c|c|c|c|}
\hline Locations & Jimma & & Mettu & Combined & \\
\hline Varieties & TI & SI & TI & TI & SI \\
\hline Bashbash & $1.853^{\mathrm{a}}$ & $-0.070^{\mathrm{ab}}$ & 1.353 & $1.77^{\mathrm{a}-\mathrm{d}}$ & $0.270^{\text {cd }}$ \\
\hline SER 119 & $1.777^{\mathrm{ab}}$ & $0.1970^{\mathrm{ab}}$ & $3.23^{\mathrm{a}-\mathrm{d}}$ & $2.513^{\mathrm{a}}$ & $0.150^{\mathrm{d}}$ \\
\hline Ayenew & $1.74^{\mathrm{ab}}$ & $0.210^{\mathrm{ab}}$ & $3.17^{\mathrm{a}-\mathrm{d}}$ & $2.270^{\mathrm{abc}}$ & $0.41^{\mathrm{abc}}$ \\
\hline SER 125 & $1.693^{\mathrm{ab}}$ & $0.020^{\mathrm{ab}}$ & $2.97^{\mathrm{a}-\mathrm{d}}$ & $2.29^{\mathrm{ab}}$ & $0.43^{\mathrm{abc}}$ \\
\hline Dimtu & $1.67^{\mathrm{abc}}$ & $-0.063^{\mathrm{ab}}$ & $2.42^{\mathrm{a}-\mathrm{e}}$ & $1.990^{\mathrm{a}-\mathrm{d}}$ & $0.203^{\mathrm{d}}$ \\
\hline Roba & $1.31^{\mathrm{bcd}}$ & $-0.010^{\mathrm{ab}}$ & $2.103^{\mathrm{b}-\mathrm{e}}$ & $1.750^{\mathrm{bcd}}$ & $0.42^{\mathrm{abc}}$ \\
\hline Naser & $1.217^{\text {cde }}$ & $0.280^{\mathrm{a}}$ & $4.017^{\mathrm{ab}}$ & $2.123^{\mathrm{abc}}$ & $0.483^{\mathrm{ab}}$ \\
\hline Gofat & $1.08^{\mathrm{de}}$ & $0.270^{\mathrm{ab}}$ & $2.81^{\mathrm{a}-\mathrm{e}}$ & $1.703^{\mathrm{bcd}}$ & $0.527^{\mathrm{a}}$ \\
\hline Melka & $1.06^{\mathrm{de}}$ & $0.013^{\mathrm{ab}}$ & $3.527^{\mathrm{abc}}$ & $1.85^{\mathrm{a}-\mathrm{d}}$ & $0.203^{\mathrm{d}}$ \\
\hline GLP 2 & $1.057^{\mathrm{def}}$ & $0.243^{\mathrm{ab}}$ & $2.77 \mathrm{a}-\mathrm{e}$ & $1.647^{\mathrm{be}}$ & $0.447^{\mathrm{abc}}$ \\
\hline Dame & $0.82^{\mathrm{efg}}$ & $-0.137 b$ & $2.00^{\mathrm{b}-\mathrm{e}}$ & $1.230^{\mathrm{d}-\mathrm{g}}$ & $0.170^{\mathrm{d}}$ \\
\hline Iboda & $0.58^{\mathrm{fg}}$ & $0.183^{\mathrm{ab}}$ & $1.67^{\text {cde }}$ & $0.933^{\mathrm{efg}}$ & $0.487^{\mathrm{a}}$ \\
\hline Awash Melka & $0.560^{\mathrm{g}}$ & $-0.030^{\mathrm{ab}}$ & $0.84^{\mathrm{e}}$ & $0.703^{\mathrm{g}}$ & $0.293^{\text {bcd }}$ \\
\hline Goberasha & $0.557^{\mathrm{g}}$ & $0.1830^{\mathrm{ab}}$ & $1.23^{\mathrm{de}}$ & $0.81^{\mathrm{fg}}$ & $0.473^{\mathrm{ab}}$ \\
\hline Awash -1 & $0.520^{\mathrm{g}}$ & $0.070^{\mathrm{ab}}$ & $4.24^{\mathrm{a}}$ & $1.517^{\mathrm{c}-\mathrm{f}}$ & $0.550^{\mathrm{a}}$ \\
\hline Mean & 1.165 & 0.085 & 2.53 & 1.673 & 0.366 \\
\hline Level significant & $* *$ & NS & $*$ & * & $* *$ \\
\hline LSD & 0.47 & 0.3819 & 2.0184 & 0.7656 & 0.1911 \\
\hline $\mathrm{CV}$ & 24.51 & 26.9 & 47.88 & 27.44 & 31.29 \\
\hline
\end{tabular}

Where, TI=tolerance index, $\mathrm{SI}=$ Susceptibility index, $\mathrm{CV}=$ coefficient of variation, $\mathrm{LSD}=$ list significant different, Note: Means with the same letters are statistically not significant $(\mathrm{p}>0.05)$ different from each other. 
Table 15. Mean values of grain yields as affected by interaction of amendments, genotypes, year and locations.

\begin{tabular}{|c|c|c|c|c|c|c|c|c|c|}
\hline \multirow{2}{*}{ Genotypes } & \multirow[t]{2}{*}{ Loc } & \multicolumn{4}{|c|}{ Year 1 (2017) } & \multicolumn{4}{|c|}{ Year 2 (2018) } \\
\hline & & $\mathbf{L}$ & Control & $\mathbf{P}$ & LP & $\mathbf{L}$ & Control & $\mathbf{P}$ & LP \\
\hline \multirow{3}{*}{ JM-ALM/H3-15-SC-1 } & Jimma & 21.33 & 20.33 & 21.00 & 22.00 & 33.33 & 29.30 & 30.30 & 30.30 \\
\hline & Haru & & & & & 16.33 & 16.33 & 18.67 & 18.67 \\
\hline & Metu & 6.33 & 6.330 & 11.33 & 12.00 & 6.670 & 9.670 & 14.33 & 11.00 \\
\hline \multirow{3}{*}{ JMALM/PR142-15-SC } & Jimma & 15.0 & 15.67 & 20.33 & 20.33 & 30.30 & 27.00 & 33.00 & 31.30 \\
\hline & Haru & & & & & 18.67 & 16.33 & 18.67 & 21.00 \\
\hline & Metu & 12.0 & 11.00 & 16.33 & 18.33 & 9.330 & 9.670 & 19.67 & 16.67 \\
\hline \multirow{3}{*}{ JM-H3/SCS-15-SG } & Jimma & 21.0 & 20.33 & 27.67 & 25.70 & 31.00 & 29.00 & 33.00 & 31.30 \\
\hline & Haru & & & & & 21.00 & 16.33 & 18.67 & 21.00 \\
\hline & Metu & 9.670 & 11.00 & 13.33 & 14.33 & 8.000 & 9.000 & 15.00 & 13.33 \\
\hline \multirow{3}{*}{ HAWASSA-04 } & Jimma & 21.67 & 23.3 & 30.0 & 26.00 & 30.00 & 29.00 & 32.70 & 31.00 \\
\hline & Haru & & & & & 23.30 & 21.00 & 23.30 & 25.70 \\
\hline & Metu & 16.0 & 15.67 & 21.33 & 20.67 & 11.33 & 13.00 & 21.00 & 17.67 \\
\hline \multirow{3}{*}{ PI423958 } & Jimma & 24.0 & 23.70 & 30.30 & 28.30 & 27.70 & 29.00 & 32.00 & 30.70 \\
\hline & Haru & & & & & 16.33 & 9.330 & 9.330 & 18.67 \\
\hline & Metu & 7.00 & 5.33 & 15.33 & 19.67 & 14.00 & 16.67 & 23.00 & 19.33 \\
\hline \multirow{3}{*}{ BRS268 } & Jimma & 20.0 & 18.67 & 23.00 & 23.00 & 29.30 & 28.30 & 31.30 & 28.70 \\
\hline & Haru & & & & & 21.00 & 18.67 & 23.30 & 23.30 \\
\hline & Metu & 11.33 & 13.33 & 14.33 & 13.00 & 10.67 & 12.33 & 15.67 & 13.33 \\
\hline \multirow{3}{*}{ JM-HAR/DAV-15-SA } & Jimma & 22.70 & 26.30 & 21.00 & 26.30 & 29.70 & 29.70 & 28.70 & 31.30 \\
\hline & Haru & & & & & 21.00 & 18.67 & 25.70 & 23.30 \\
\hline & Metu & 7.00 & 6.670 & 12.67 & 18.33 & 7.000 & 12.33 & 16.00 & 12.30 \\
\hline \multirow{3}{*}{ SCS-1 } & Jimma & 20.33 & 19.67 & 23.70 & 21.67 & 29.70 & 29.70 & 31.00 & 31.00 \\
\hline & Haru & & & & & 18.67 & 18.67 & 16.33 & 21.00 \\
\hline & Metu & 6.33 & 5.33 & 9.33 & 12.00 & 5.330 & 7.000 & 14.67 & 10.67 \\
\hline \multirow{3}{*}{ JM-CLK/CRFD-15-SA } & Jimma & 19.0 & 19.0 & 20.00 & 21.67 & 30.30 & 29.70 & 30.30 & 30.00 \\
\hline & Haru & & & & & 21.00 & 16.33 & 21.00 & 23.30 \\
\hline & Metu & 9.33 & 6.33 & 9.00 & 13.67 & 6.000 & 11.00 & 13.67 & 11.33 \\
\hline \multirow{3}{*}{ JM-DAV/PR142-15-SA } & Jimma & 22.0 & 21.33 & 24.7 & 23.00 & 25.70 & 28.00 & 28.70 & 30.00 \\
\hline & Haru & & & & & 11.67 & 11.67 & 18.67 & 21.00 \\
\hline & Metu & 9.33 & 9.330 & 8.670 & 10.67 & 4.000 & 7.670 & 14.00 & 6.00 \\
\hline \multirow{3}{*}{$\mathrm{H}-7$} & Jimma & 15.00 & 16.00 & 20.67 & 18.33 & 29.00 & 23.30 & 25.30 & 21.67 \\
\hline & Haru & & & & & 14.00 & 11.67 & 16.33 & 23.30 \\
\hline & Metu & 8.00 & 8.33 & 12.00 & 15.00 & 7.330 & 11.00 & 15.33 & 15.00 \\
\hline \multirow{3}{*}{ JM-PR142/H3-15-SB } & Jimma & 23.3 & 20.33 & 28.00 & 25.70 & 25.00 & 24.70 & 23.30 & 21.67 \\
\hline & Haru & & & & & 23.30 & 16.33 & 23.30 & 28.00 \\
\hline & Metu & 13.33 & 10.33 & 15.00 & 16.67 & 7.000 & 10.00 & 18.33 & 15.00 \\
\hline \multirow{3}{*}{ JM-CLK/G99-15-SB } & Jimma & 21.33 & 21.67 & 25.00 & 21.33 & 22.7 & 23.3 & 26.30 & 24.00 \\
\hline & Haru & & & & & 21.00 & 11.67 & 14.00 & 25.70 \\
\hline & Metu & 10.67 & 7.67 & 9.00 & 11.33 & 4.67 & 8.33 & 10.33 & 10.67 \\
\hline \multirow{3}{*}{ JM-CLK/G99-15-SC } & Jimma & 20.67 & 22.00 & 24.7 & 22.3 & 24.3 & 23.7 & 24.00 & 24.30 \\
\hline & Haru & & & & & 16.33 & 9.33 & 14.00 & 18.67 \\
\hline & Metu & 7.670 & 8.33 & 11.67 & 11.33 & 4.33 & 8.00 & 10.67 & 7.67 \\
\hline \multirow{3}{*}{ PI567046A } & Jimma & 17.67 & 16.00 & 19.67 & 16.33 & 13.67 & 15.33 & 14.67 & 15.33 \\
\hline & Haru & & & & & 9.33 & 9.33 & 11.67 & 16.33 \\
\hline & Metu & 19.33 & 10.67 & 15.33 & 20.67 & 13.67 & 10.67 & 16.00 & 15.33 \\
\hline Mean & & 18.25 & & & & & & & \\
\hline $\mathrm{CV}$ & & 17.67 & & & & & & & \\
\hline
\end{tabular}

Where, $\mathrm{L}=$ recommended lime alone, $\mathrm{p}=$ recommended phosphorus alone, $\mathrm{LP}=$ both recommended lime and phosphorus treated, $\mathrm{LSD}=$ list significant different, Loc $=$ location, $C V=$ coefficient of variation.

Table 16. Combined mean grain yield of genotypes over locations and years with their corresponding ranks under control soil conditions.

\begin{tabular}{llll}
\hline №. & Genotypes, varieties and lines & Yield (quintal/ha) & Rank \\
\hline 1 & HAWASSA-04 & 20.24 & $1^{\text {st }}$ \\
2 & JM-HAR/DAV-15-SA & 18.36 & $2^{\text {nd }}$ \\
3 & BRS-268 & 17.88 & $3^{\text {rd }}$ \\
4. & JM-H3/SCS-15-SG & 16.89 & $4^{\text {th }}$ \\
5. & JM-PR142/H3-15-SB & 16.17 & $5^{\text {th }}$ \\
\hline
\end{tabular}


Table 17. Tolerance index of soybean genotypes for yield and plant height at individual locations on acid soil.

\begin{tabular}{|c|c|c|c|c|c|c|}
\hline Locations & Jimma & & Mettu & & Haru & \\
\hline Genotypes & Yield & Plant height & Yield & Plant height & Yield & Plant height \\
\hline JM-HAR/DAV-15-SA & $1.460^{\mathrm{a}}$ & $1.217^{\mathrm{bc}}$ & $1.55^{\mathrm{ef}}$ & $1.047^{\mathrm{de}}$ & $2.02^{\mathrm{abc}}$ & $0.997^{\text {ef }}$ \\
\hline PI423958 & $1.437^{\mathrm{a}}$ & $1.210^{\mathrm{bc}}$ & $2.25^{\mathrm{b}}$ & $0.933^{\mathrm{e}}$ & $0.7467^{\mathrm{d}}$ & $0.513^{\mathrm{g}}$ \\
\hline HAWASSA-04 & $1.40^{\mathrm{ab}}$ & $1.247^{\mathrm{bc}}$ & $2.83^{\mathrm{a}}$ & $1.48^{\mathrm{b}}$ & $2.477^{\mathrm{a}}$ & $1.170^{\text {de }}$ \\
\hline JM-H3/SCS-15-SG & $1.290^{\mathrm{abc}}$ & $1.287^{\mathrm{b}}$ & $1.47^{\mathrm{f}}$ & $1.413^{\mathrm{b}}$ & $1.573^{\mathrm{abcd}}$ & $1.337^{\mathrm{d}}$ \\
\hline JM-ALM/H3-15-SC-1 & $1.18^{\mathrm{bcd}}$ & $0.950^{\mathrm{d}}$ & $1.0^{\mathrm{gh}}$ & $1.10^{\text {cd }}$ & $1.423^{\mathrm{bcd}}$ & $1.14^{\text {def }}$ \\
\hline JM-DAV/PR142-15-SA & $1.177^{\mathrm{bcd}}$ & $0.580^{\mathrm{e}}$ & $0.757^{\mathrm{h}}$ & $0.783^{\mathrm{f}}$ & $1.123^{\mathrm{cd}}$ & $0.633^{\mathrm{g}}$ \\
\hline SCS-1 & $1.177^{\mathrm{bcd}}$ & $1.017^{\mathrm{cd}}$ & $0.747^{\mathrm{h}}$ & $1.09^{\mathrm{cd}}$ & $1.797^{\mathrm{abc}}$ & $1.277^{\mathrm{d}}$ \\
\hline JM-CLK/CRFD-15-SA & $1.133^{\text {bcde }}$ & $0.967^{\mathrm{d}}$ & $1.183^{\mathrm{g}}$ & $1.163^{\mathrm{c}}$ & $1.873^{\mathrm{abc}}$ & $1.280^{\mathrm{d}}$ \\
\hline BRS268 & $1.133^{\text {cde }}$ & $1.420^{\mathrm{ab}}$ & $1.81^{\text {cde }}$ & $1.45^{\mathrm{b}}$ & $2.02^{\mathrm{abc}}$ & $1.870^{\mathrm{b}}$ \\
\hline JMALM/PR142-15-SC & $1.010^{\text {cde }}$ & $0.830^{\mathrm{d}}$ & $1.947^{\mathrm{cd}}$ & $1.153^{\mathrm{c}}$ & $1.573^{\mathrm{abcd}}$ & $1.293^{\mathrm{d}}$ \\
\hline JM-CLK/G99-15-SC & $0.990^{\text {de }}$ & $0.950^{\mathrm{d}}$ & $0.790^{\mathrm{h}}$ & $1.093^{\text {cd }}$ & $0.823^{\mathrm{d}}$ & $0.920^{\mathrm{f}}$ \\
\hline JM-PR142/H3-15-SB & $0.990^{\text {ed }}$ & $1.40^{\mathrm{ab}}$ & $1.687^{\mathrm{def}}$ & $1.38^{\mathrm{b}}$ & $2.097^{\mathrm{ab}}$ & $1.633^{\mathrm{c}}$ \\
\hline JM-CLK/G99-15-SB & $0.937^{\text {ef }}$ & $0.92^{\mathrm{d}}$ & $0.913^{\mathrm{gh}}$ & $1.07^{\mathrm{cd}}$ & $1.35^{\mathrm{bcd}}$ & $1.0167^{\mathrm{ef}}$ \\
\hline $\mathrm{H}-7$ & $0.720 \mathrm{f}$ & $0.56^{\mathrm{e}}$ & $1.48^{\mathrm{f}}$ & $0.68^{\mathrm{f}}$ & $1.273^{\mathrm{bcd}}$ & $0.610^{\mathrm{g}}$ \\
\hline PI567046A & $0.453 \mathrm{~g}$ & $1.62^{\mathrm{a}}$ & $2.0367^{\mathrm{bc}}$ & $3.15^{\mathrm{a}}$ & $0.673^{\mathrm{d}}$ & $2.610^{\mathrm{a}}$ \\
\hline Mean & 1.0944 & 1.076 & 1.149 & 1.265 & 1.522 & 1.219 \\
\hline LSD & 0.2367 & 0.2239 & 0.285 & 0.1141 & 0.95 & 0.2298 \\
\hline $\mathrm{CV}$ & 12.99 & 12.44 & 11.41 & 5.393 & 37.39 & 11.27 \\
\hline
\end{tabular}

Where, $\mathrm{CV}=$ coefficient of variation, $\mathrm{LSD}=$ list significant different, Note: Means with the same letters are statistically not significant ( $\mathrm{p}>0.05)$ different from each other.

\section{Conclusion}

More than ten-twenty years of efforts in soil acid soil management practices for annual crops production is reviewed. In this document, the annual crops refer to maize, soybean and common bean. I highlighted a wide range of soil acidity management practices such as using liming, organic amendment, using acid tolerant variety, integrated lime with organic, lime with inorganic and integrated soil fertility management. Infertile soils and acid soils are similar in most cases and hence their managements also similar. They are major constraint in crop production. The 33: 33: 33 combinations of lime: vermi-compost and chemical $P$ fertilizer resulted in similar grain and biomass yield of maize with recommended chemical fertilizer. Strong acid soils $(>5.5$ in $\mathrm{pH})$ should be amended with lime before fertilizer use. The practice of liming acid soils to mitigate soil acidity has been recognized for optimal crop production in acid soils of Jimma area. Liming should be coupled with the applications of optimum rates of inorganic and organic fertilizers, particularly P fertilizers. Using organic fertilizer can also be considered as an option for reclaiming acid soil. Overall, liming should be considered as a soil amendment to raise soil $\mathrm{pH}$ to the level that is suitable for maximum nutrient availability, plant growth, and crop yield. For a long term solution, identifying acid soil tolerant genotypes is an important practices and Hawassa 04 genotype is an example in that it is acid soil tolerant genotype.

Crops differ widely in their ability to tolerate acid soil conditions. These differences provide a good possibility for selection and breeding plants for improved tolerance to soil acidity, a low cost and effective alternative to the high cost of amending acid soil using lime. In general, the integrated use of all the available resources including acid tolerant crops and crop species, which improve and sustain soil and agricultural productivity, is of great practical significance. Overall, acid soil management needs to emphasize strategic research, integrating soil and water management with improved crop varieties and environmentally benign technologies for sustained food production within a framework of appropriate socio-economic and policy considerations.

\section{Competing Interests}

The authors declare that they have no competing interests.

\section{Acknowledgements}

The Author grateful to Jimma Agricultural Research Center for facilitating/providing reference material during this review writing work.

\section{References}

[1] Achalu Chimdi, Heluf Gebrekidan, Kibebew Kibret, Abi Tadesse. Response of barley to liming of acid soils collected from different land use systems of Western Oromia, Ethiopia. Journal of Biodiversity and Environmental Sciences. 2012; 2 (7): 1-13.

[2] Agegnehu, G., and Amede, T. (2017). Integrated soil fertility and plant nutrient management in tropical agro-ecosystems: A review. Pedosphere 27, 662-680.

[3] Brady C. and R. Weil, 2002. The nature and properties of soils, 13th. Pearson education (Singapore) Pte. Ltd. Indian Branch, 482: 621-624.

[4] Delhaize E., D. Gruber and R. Ryan, 2007. The roles of organic anion permeases in aluminium resistance and mineral nutrition. Febs Letters, 581: 2255-2262. 
[5] Ethiosis., 2014. Soil fertility mapping and fertilizer blending. Agricultural Transformation Agency (ATA) Report, Ethiopia soil information system (Ethiosis). Ministry of Agriculture, Addis Ababa.

[6] Fageria NK, Santos AB. Influence of $\mathrm{pH}$ on productivity, nutrient use efficiency by dry bean, and soil phosphorus availability in a no-tillage system. Communication in Soil Science and Plant Analysis. 2008; 39: 1016- 1025.

[7] Fageria, N., and Baligar, V. (2008). Ameliorating soil acidity of tropical Oxisols by liming for sustainable crop production. Adv. Agron. 99, 345-399.

[8] Hirpa L., D. Niguse, G. Setegn, B. Geremew and M. Firew, 2013. Response to soil acidity of common bean genotypes (Phaseolus vulgaris L.) under field conditions at Nedjo, western Ethiopia. Science, Technology and Arts Research Journal, 2: 03-15.

[9] Liu P, Yang YS, Xu GD, Zhu SL. The effect of aluminum stress on morphological and physiological characteristics of soybean root of seedling. Chin J Oil Crop Sci. 2004; 26 (4): 49-54.

[10] Mengesha D, Mekonnen L. and Manjh (2014) Integrated agronomic crop managements to improve teff productivity under terminal drought. Water Stress, I. Md, M. Rahman, and
H. Hasegawa, Eds., Intech Open Science, London, UK. 2012; 235-254.

[11] Mesfin A., 2007. Nature and management of acid soils in Ethiopia. Addis Ababa, Ethiopia. 99 p.

[12] Nekesa O., R. Okalebo, O. Othieno, N. Thuita, M. Kipsat, A. Bationo, N. Sanginga, J. Kimettu and B. Vanlauwe, 2005. The potential of Minjingu phosphate rock from Tanzania as a liming material: effect on maize and bean intercrop on acid soils of western Kenya. African Crop Science Conference Proceedings, 7: 1121-1128.

[13] Sanchez A and G. Salinas, 1981. Low-input technology for managing Oxisols and Ultisols in tropical America. In Advances in agronomy 34: 279-406. Academic Press.

[14] Verde S., B. Danga, M. Oginga, N. Jayne, and Sharma 2013. Effects of manure, lime and mineral $\mathrm{P}$ fertilizer on soybean yields and soil fertility in a humic Nitisol in the Central Highlands of Kenya. International Journal of Agricultural Science Research, 2: 283-291.

[15] Wang P., H. Raman, P. Zhang, N. Mendham and X. Zhou, 2006. Aluminium tolerance in barley (Hordeum vulgare L.): physiological mechanisms, genetics and screening methods. Journal of Zhejiang University SCIENCE B, 7: 769-787. 